\title{
EXPERIMENTAL INVESTIGATION OF THERMAL PERFORMANCE OF LIQUID FLAT PLATE COLLECTOR BY COMPARING SINGLE GLASS SHEET WITH THE DOUBLE GLASS SHEET
}

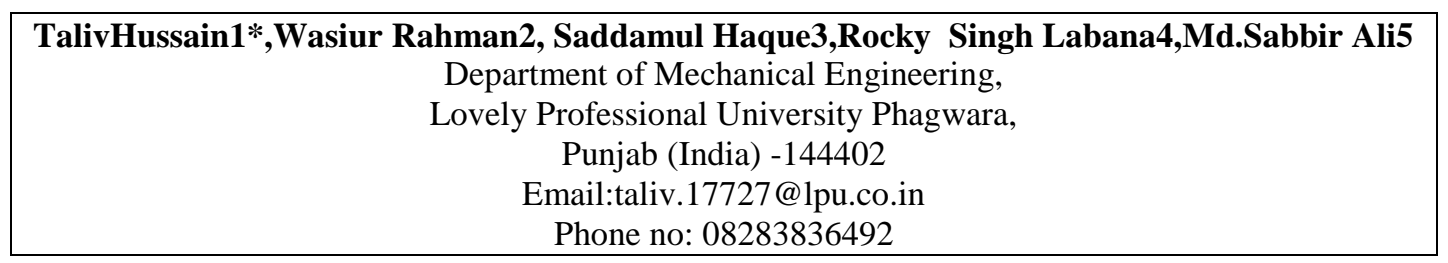

\begin{abstract}
With the rapid exhaustion of natural resource there is upsurge in utilization of nonconventional resources. Being abundance in availability and non-polluting in nature they are given preference over fossil fuels. With the advancement of technical era it gave birth to new devices which are utilized to harness non-conventional energy. Few of them are solar collectors and wind mills. In this experiment we are harnessing solar energy using solar flat plate collector. We are varying the use of glass sheet to determine collector efficiency. In first instance we are using single glass sheet as the outer shield and in second instance pair of glass is used. To enhance the performance of solar collector we use toughen glass sheet, because of its better optical property. Toughen glass sheet of $5 \mathrm{~mm}$ is used in the experiment. After comparing and contrasting the efficiency of two experiments conducted using single and double glass sheet, we concluded that the setup having single glass sheet is more efficient than the double glass sheet. Efficiency of solar collector is enhanced by $28-32 \%$, if single glass sheet of better optical property is taken into consideration.
\end{abstract}

Keywords: Solar Flat plate Collector, Collector Efficiency.

\section{INTRODUCTION}

With the depletion of natural resource like fossil fuels the world is on the verge of witnessing major setback of energy crisis. Energy growth is going on in arithmetic way where as its consumption is increasing in geometrical way. With the natural resources hitting new lows with each passing days, it has dented the economy of many countries which relied heavily on them. It is a matter of great concern not only for us but also for our coming generation, looking at current scenario of energy consumption it's not very difficult to predict that the energy resource will not last much longer. The scientists are working hard on finding alternative of these resources. One of the best alternatives for prevention of depletion of the energy resources is use of non-conventional energy, which is available in abundance around us. They are majorly solar, wind and tidal energy. These natural resources are harnessed to produce energy which can be utilised for performing various activities. Non conventional energy resource turns out to be boon in this acute energy crisis situation. Non conventional energy is far much better than the fossil fuels and other resources. In terms of availability, cost, affect on environment and many more factors under which non conventional energy is preferable over fossil fuels. The only factor which underlines the advantage is its sparsely distribution across the earth. With the advancement of technical era, more and more technology is put into work to harness non conventional energy. Major products being solar cell and wind mill are the gift of technology. Our area of concern is solar liquid collector, which utilizes solar energy to heat up water which is used for domestic as well as industrial purpose.

\section{LITERATURE REVIEW}

k. Chung et al: An experiment is conducted to evaluate the pressure variation on the collector and the wind uplift force. Two suggestions are composed to reduce the wind uplift; these are lifting the model and guide plate. Wind speed used for the evaluation of wind uplift is in the range of $20-50 \mathrm{~m} / \mathrm{sec}$. There is significant effect on wind uplift using guide plate normal to the wind. The effect of lifting the model is not much effective to reduce the wind lift. Ahmet Koca et al: an experiment is performed to evaluate the exergy and energy performance of the integrated flat plate solar collector with phase changing material for thermal storage. Mobilterm 605 is used as a working fluid with thermal conductivity $.145 \mathrm{~W} / \mathrm{mK}$. PCM material used is $\mathrm{CaCl}_{2} \cdot 6 \mathrm{H}_{2} \mathrm{O}$. 


\section{III.EXPERIMENTAL SETUP}

Energy and exergy efficiencies are $45 \%$ and $2.2 \%$.

Katharina Resch et al: a review is done on the Thermotropic layers used for the overheating protection. Their transmittance is the function of the temperature of the collector. At greater temperatures transmittance declines reduce the collector temperature. Thermotropic hydrogels, thermotropic polymer blends and thermotropic systems with fixed domain are mainly applied for overheating protection. Ahreza Hobbi et al: To observe the effect of heat enhancement devices on collector performance an experiment is being conducted. Basically four different types of arrangement are analyzed regular circular tube, regular tube with twisted strip tabulator, regular tube with coil spring wire and regular tube with conical ridges installed in every $152 \mathrm{~mm}$. There is meagre effect on the performance of collector. Hamid Moghadam et al: Developed the optimum tilt angle for the flat plate solar collector to receive maximum solar radiation. A MATLAB program is developed to evaluate the optimum tilt angle on the day basis, month basis, annual basis or any specified time interval. The results are constant with experimental data. Naiem Akhtaret et al: observed the changing effect of absorption of radiation in glass cover on the top loss coefficient for single and double glass cover. Temperature of the glass cover is increased by $6^{\circ} \mathrm{c}$ in case of single glazing. Temperature of the glass cover is increased by $14^{\circ} \mathrm{c}$ and $11^{\circ} \mathrm{c}$ in case of double glazing. There is a difference of $49 \%$ in the value of convective heat transfer coefficient, by taking and neglecting the absorption in glass cover in case of double glazing. The correlations are developed for to compute the absorption effect in the glass cover. Y. Raja Sekhar et al: To detect the loss coefficient considering the aspects like insulation, emissivity of absorber, ambient temperature, wind loss coefficient, and tilt an experiment is conducted. Apart from experiment they are also theoretically analyzed. After analysing both experimental $n$ analytical process following conclusion is drawn, efficiency reduces with increment in emissivity of the plate, efficiency elevates with increase in ambient temperature, with increase in wind loss coefficient efficiency decrease, not much changes occur due to tilt on top loss coefficient.
The setup used in the experiment consists of a wooden frame, a thin glass sheet, aluminium sheet, copper pipe and insulating material. The dimension of wooden frame is $900 \mathrm{~mm} \times 1245 \mathrm{~mm}$. Wooden frame is being insulated using glass wool having 5 $\mathrm{cm}$ thickness, copper pipe of $10 \mathrm{~mm}$ diameter is placed which is brazed over by aluminium sheet of $3 \mathrm{~mm}$ thickness. In this experiment we explore the collector efficiency yielded by the solar flat plate collector under the action of single and pair of glass. Thickness of both glass sheets is same i.e 5 $\mathrm{mm}$. We make use of toughen glass as the outer covering of the solar panel where sun rays falls directly. After passing through the glass, rays reaches the aluminium plate which gets heated up due to the action of sun rays over them, this heated plate heats up the copper coil running beneath it by convective heat. Water running inside the coil also gets heated up. Water is supplied from one end of the pipe and temperature is observed at the inlet as $T_{1}$, as water flows through the pipe it extracts heats from the copper coil resultant gets heated up and water received at the outlet has comparatively higher temperature than its inlet, outlet temperature is measured as $T_{2}$. During first setup single glass is used in experiment and observation is recorded and then double glass is used and recording is taken accordingly.

The dimensions of tubes are:

\begin{tabular}{|c|c|}
\hline $\begin{array}{c}\text { Inner Diameter of } \\
\text { Tube }\end{array}$ & $10 \mathrm{~mm}$ \\
\hline Thickness of Tube & $2 \mathrm{~mm}$ \\
\hline Spacing between & $100 \mathrm{~mm}$ \\
\hline
\end{tabular}




\section{ELK}

\section{Asia Pacific Journals}

\begin{tabular}{|l|l|}
\hline Tubes & \\
\hline
\end{tabular}

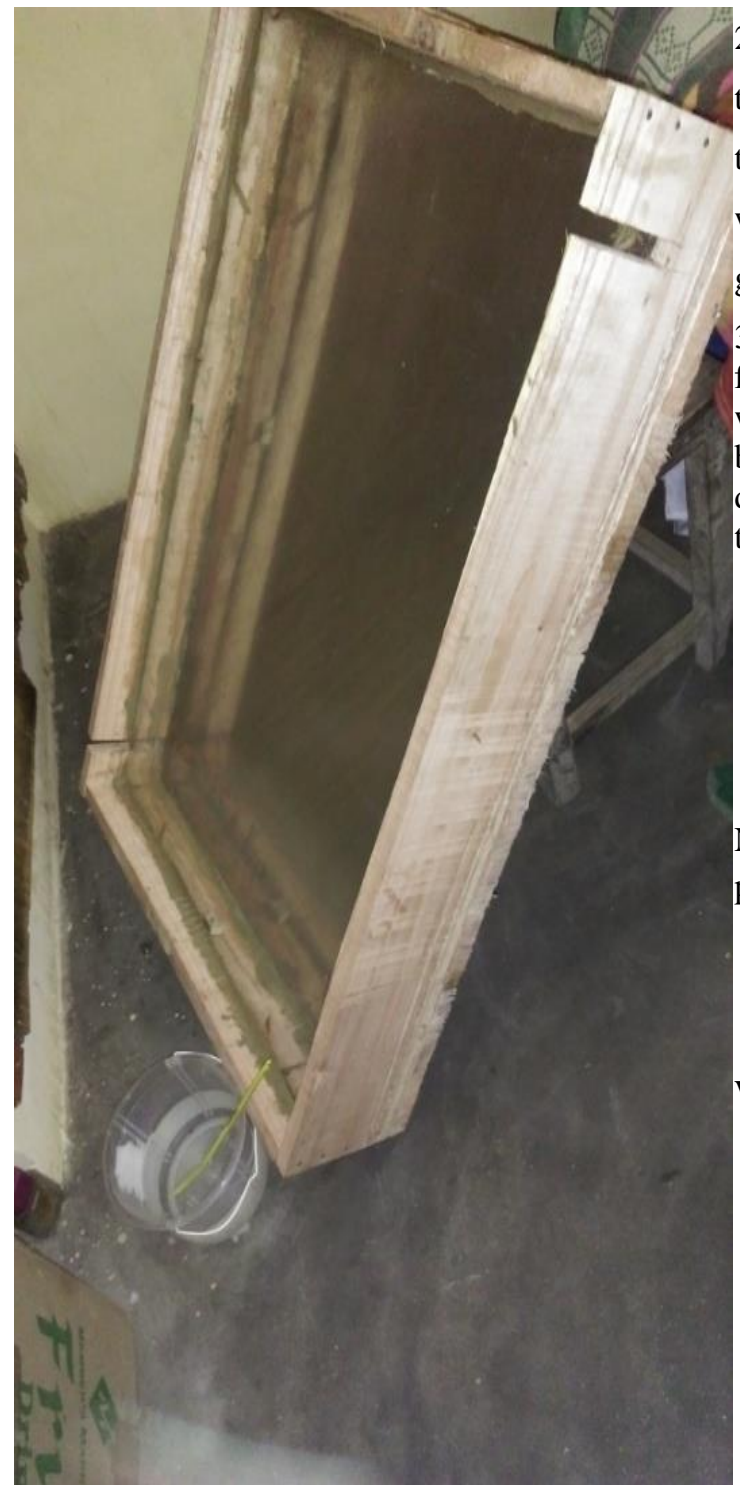

Figure 1. Liquid flat plate collector
1. Solar power meter: Solar power meter is used to measure intensity of radiation falling on collector Surface in watt $/ \mathrm{m}^{2}$

2. Temperature Sensor: The Dial gauge type temperature sensor is used to measure the temperature of the inlet and outlet water from the water flat plate collector. The range of the dial gauge type temperature sensor is from $0-250^{\circ} \mathrm{C}$.

3. Liquid mass flow rate Measurement: The liquid flow rate is measured by conventional method in which we have recorded the time required to fill the beaker of known volume. By the help of this data,we have calculated discharge(volume/time) at the outlet of the water flat plate collector.

\section{IV.CALCULATION AND RESULT}

Now, we can determine the efficiency of solar flat plate collector using the formula:

$$
\eta=m c \Delta t / I A
$$

Where, $\mathrm{m}=$ mass flow rate

$$
\begin{aligned}
& \mathrm{c}=\text { specific heat capacity } \\
& \Delta \mathrm{t}=\mathrm{T}_{2}-\mathrm{T}_{1} \\
& \mathrm{I}=\text { intensity of sun rays } \\
& \mathrm{A}=\text { area of solar flat plate collector }
\end{aligned}
$$

Measuring devices and instruments

The different parameters are measured in this study. The instruments used are as follows:

1. Solar power meter

2. Temperature Sensor

3. Liquid mass flow rate Measurement 
Asia Pacific Journals

Table 1. Data obtained in experiment (WHEN SINGLE GLASS SHEET IS USED)

\begin{tabular}{|c|c|c|c|c|c|c|}
\hline Time & $\begin{array}{c}\text { Outlet } \\
\text { Temperature of } \\
\text { water } \\
\left.\mathrm{T}_{2}\left(\text { in }^{\circ} \mathrm{C}\right)\right)\end{array}$ & $\begin{array}{c}\text { Inlet } \\
\text { Temperature of } \\
\text { water } \\
\mathrm{T}_{1}\left(\text { in }{ }^{\circ} \mathrm{C}\right)\end{array}$ & $\begin{array}{c}\text { Water Flow } \\
\text { Rate } \mathrm{M}_{\mathrm{f}} \\
(\mathrm{kg} / \mathrm{s})\end{array}$ & $\begin{array}{c}\text { Solar } \\
\text { Intensity } \\
\mathrm{I}\left(\mathrm{W} / \mathrm{m}^{2}\right)\end{array}$ & $\begin{array}{c}\text { Temperature } \\
\text { difference } \\
\Delta \mathrm{T} \\
\left(\mathrm{T}_{2}-\mathrm{T}_{\mathrm{I}}\right) \quad \text { (in } \\
\left.{ }^{\circ} \mathrm{C}\right)\end{array}$ & $\begin{array}{c}\text { Efficiency } \\
\qquad \begin{array}{c}\eta \\
\text { in } \%\end{array}\end{array}$ \\
\hline 10:00 AM & 29 & 25 & 0.008 & 610 & 4 & 20.1 \\
\hline 11:00 AM & 33 & 25 & 0.008 & 680 & 8 & 35.2 \\
\hline 12:00 PM & 37 & 25 & 0.008 & 750 & 12 & 47.4 \\
\hline 1:00 PM & 41 & 25 & 0.008 & 800 & 16 & 60.1 \\
\hline 2:00 PM & 38 & 25 & 0.008 & 755 & 13 & 51.1 \\
\hline 3:00 PM & 34 & 25 & 0.008 & 685 & 9 & 40.2 \\
\hline 4:00 PM & 28 & 25 & 0.008 & 600 & 3 & 15.3 \\
\hline
\end{tabular}

Table 2. Data obtained in experiment (WHEN DOUBLE GLASS SHEET IS USED)

\begin{tabular}{|c|c|c|c|c|c|c|}
\hline Time & $\begin{array}{c}\text { Outlet } \\
\text { Temperature of } \\
\text { water } \\
\left.\mathrm{T}_{2}\left(\text { in }{ }^{\circ} \mathrm{C}\right)\right)\end{array}$ & $\begin{array}{c}\text { Inlet } \\
\text { Temperature of } \\
\text { water } \\
\mathrm{T}_{1}\left(\text { in }{ }^{\circ} \mathrm{C}\right)\end{array}$ & $\begin{array}{c}\text { Water Flow } \\
\text { Rate } \mathrm{M}_{\mathrm{f}} \\
(\mathrm{kg} / \mathrm{s})\end{array}$ & $\begin{array}{c}\text { Solar } \\
\text { Intensity } \\
\mathrm{I}\left(\mathrm{W} / \mathrm{m}^{2}\right)\end{array}$ & $\begin{array}{c}\text { Temperature } \\
\text { difference } \\
\Delta \mathrm{T} \\
\left(\mathrm{T}_{2}-\mathrm{T}_{\mathrm{I}}\right) \quad \text { (in } \\
\left.{ }^{\circ} \mathrm{C}\right)\end{array}$ & $\begin{array}{c}\text { Efficiency } \\
\qquad \begin{array}{c}\eta \\
\text { in } \%\end{array}\end{array}$ \\
\hline 10:00 AM & 28 & 25 & 0.008 & 610 & 3 & 15.2 \\
\hline 11:00 AM & 31 & 25 & 0.008 & 680 & 6 & 26.1 \\
\hline 12:00 PM & 35 & 25 & 0.008 & 750 & 10 & 40.1 \\
\hline 1:00 PM & 38 & 25 & 0.008 & 800 & 13 & 48.4 \\
\hline 2:00 PM & 36 & 25 & 0.008 & 755 & 11 & 44.1 \\
\hline 3:00 PM & 32 & 25 & 0.008 & 685 & 7 & 31.2 \\
\hline
\end{tabular}



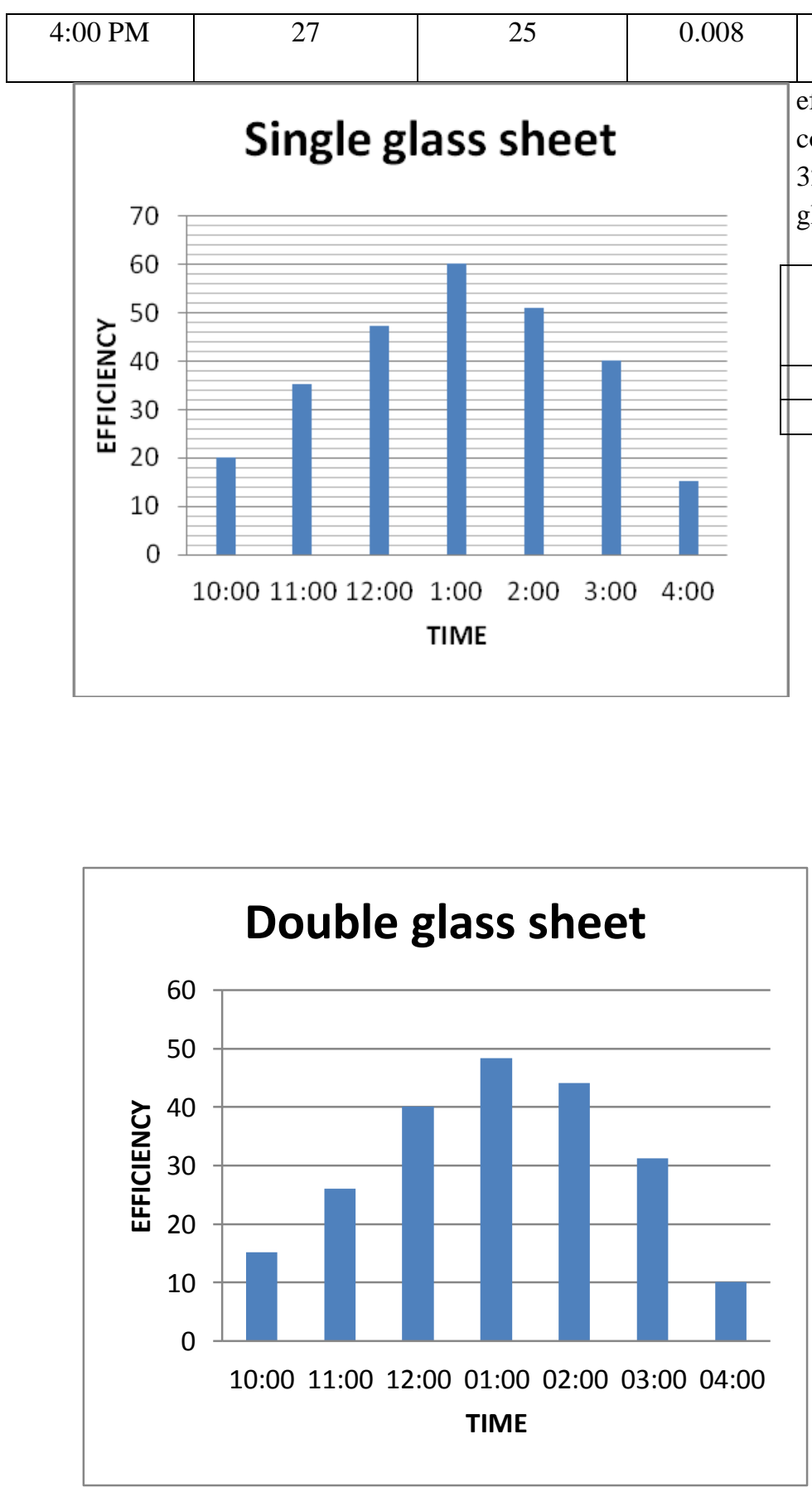

\section{V.CONCLUSION}

After conducting the experiments using same mass flow rate of water in the case of single glass and double glass sheet we came to conclude that collector efficiency is maximum for single glass cover as compare to double glass cover. Thus there is an 28$32 \%$ increase in collector efficiency on using single glass sheet of better quality.

\begin{tabular}{|c|c|c|}
\hline $\begin{array}{c}\text { Glass sheet } \\
\text { used }\end{array}$ & $\begin{array}{c}\text { Maximum } \\
\text { Efficiency }(\%)\end{array}$ & $\begin{array}{c}\text { Maximum } \\
\text { Temp. } \\
\text { Difference }\left({ }^{\circ} \mathrm{C}\right)\end{array}$ \\
\hline Single & 60.1 & 16 \\
\hline Double & 48.4 & 13 \\
\hline
\end{tabular}

\section{REFERENCES}

[1] K. Chung, K. Chang and Y. Liu, Reduction of wind uplift of a solar collector model, Journal of wind engineering and Industrial Aerodynamics, 96 (2008) 1294-1306

[2] Ahmet Koca Forecasting of thermal energy storage performance of Phase Change Material in a solar collector using soft computing techniques, Expert Systems with Applications, 37 (2010)2724-2732

[3] Atharina Resch Thermotropic layers for flatplate collector - A review of various concepts for overheating protection with Polymeric materials, Solar energy materials \& solar cells, 93 (2009)119-128

[4] G.D.Rai, Non-conventional Source of Energy, fourth Edition, Eighteenth reprint:2006

[5] B.H.Khan, Non-Conventional Source of Energy, Second Edition, Seventh reprint:2011

[6 ] Ismail.H. Ozsabuncuoglu, Economic analysis of flat plate collectors of solar energy, energy policy, 23, no.9 (1995)-755-763 